\title{
Identification of Sources of Bacterial Wilt Resistance in Common Bean (Phaseolus vulgaris)
}

\author{
Carlos A. Urrea and Robert M. Harveson, University of Nebraska, Panhandle Research and Extension Center, Scottsbluff 69361
}

\begin{abstract}
Urrea, C. A., and Harveson, R. M. 2014. Identification of sources of bacterial wilt resistance in common bean (Phaseolus vulgaris). Plant Dis. 98:973-976.

Over the last decade, bacterial wilt, caused by Curtobacterium flaccumfaciens pv. flaccumfaciens, has reemerged in the Central High Plains (Nebraska, Colorado, and Wyoming) and has been identified in almost 500 fields. Affected fields were planted with bean (Phaseolus vulgaris) from multiple market classes and seed sources, including yellow, great northern, pinto, kidney, cranberry, black, navy, pink, and small red, and incidence varied from trace levels to $>90 \%$. One wiltresistant bean, 'Emerson', is available today but it is grown on a limited basis as a specialized cultivar for targeted markets in Europe and cannot be grown in all fields where the disease has recently been identified. Thus, we are faced with an emerging problem that must be addressed by utilizing newly developed resistant cultivars. This study was initiated to evaluate the Phaseolus National Plant Germplasm System (NPGS) bean collection for resistance to C. flaccumfaciens pv. flaccumfaciens in the ongoing effort to develop a new wilt-resistant cultivar adapted to this region. In total, 467 entries, including accessions

from the NPGS, several commercial great northern and pinto cultivars, and University of Nebraska experimental lines, were screened with a highly virulent orange strain of $C$. flaccumfaciens pv. flaccumfaciens previously recovered from an infected great northern bean plant in Nebraska. Bacterial wilt severity ratings were 1.0 to 9.0 (0 to $90 \%$ incidence). Of the 427 accessions from the NPGS, only 1 showed resistance $(0.23 \%), 19$ showed intermediate resistances $(4.45 \%)$, and the remainder were susceptible $(95.34 \%)$. PI 325691 was identified as a source of bacterial wilt resistance. It was screened against six additional $C$. flaccumfaciens pv. flaccumfaciens strains and still produced resistant reactions. PI 325691 is a wild common bean $(P$. vulgaris) collected 8 miles South of Tzitzio, Michoacán, Mexico; however, it has a small seed size $\left(5.3 \mathrm{~g} 100^{-1}\right.$ seeds $)$ that is commercially unacceptable. It will take several backcrosses to transfer this resistance to bacterial wilt and recover the seed size into a cultivated bean.
\end{abstract}

Bacterial wilt, caused by Curtobacterium flaccumfaciens pv. flaccumfaciens, was first identified from South Dakota in 1926 (11), and then became one of the most problematic bacterial diseases in the United States, particularly throughout the irrigated high plains and Midwest. It was an endemic problem in western Nebraska dry bean (Phaseolus vulgaris L.) production during the 1960s and early 1970s but essentially disappeared (i.e., would only sporadically appear in seed and had no detectable effect on yield) with implementation of seed sanitation and crop rotation $(6,7)$.

C. flaccumfaciens pv. flaccumfaciens is a seedborne pathogen $(12,15)$, and is characterized by gram-positive, short, pleomorphic rods with a bending or snapping morphology, referred to as "coryneform". Several pathogen color variants have been identified that may discolor infected seed, making them yellow, orange, or purple, and sometimes no symptoms are observed $(5,12)$. Symptoms in bean fields consist of interveinal, necrotic lesions surrounded by yellow borders. These lesions tend to be irregular and water soaking is generally not observed. Infected plants also exhibit wilting during periods of moisture stress due to blockage of water movement within the vascular tissues by the pathogen $(4,5)$. Damage is more severe if plants become infected early as seedlings or are subjected to other stresses such as drought or hailstorms (5).

C. flaccumfaciens pv. flaccumfaciens is considered an A2 quarantine pest in Europe and is subject to phytosanitary regulations in some countries (3). Hence, national and international movement of bean seed could negatively affect bean seed production in affected areas in Nebraska.

Corresponding author: C. A. Urrea, E-mail: currea2@unl.edu

Accepted for publication 31 January 2014.

http://dx.doi.org/10.1094/PDIS-04-13-0391-RE

(C) 2014 The American Phytopathological Society
Resistant 'Emerson' bean (2) was developed during the early 1970 s by the University of Nebraska specifically for managing bacterial wilt, demonstrating the importance that this disease once held. Breeding for resistance was later discontinued when it was determined that using seed sanitation, increasing disease-free seed in dry climates, and using proper crop rotations effectively stopped the introduction of the pathogen.

Over the last 8 to 10 years, the pathogen has reemerged in the Central High Plains (Nebraska, Colorado, and Wyoming) and has been identified from more than 500 fields $(6,7,10)$, with incidence in fields varying from greater than $90 \%$ to trace levels. Problem fields consisted of bean plants from multiple market classes and seed sources, including yellow, great northern, pinto, kidney, cranberry, black, navy, pink, and small red (7).

Losses in both yield and quality have been demonstrated. During 2003, some heavily infested fields in Nebraska were estimated to yield up to two-thirds less than would be expected of a typical crop (10). Incidence of discolored seed collected from infected plants averaged $25 \%$, whereas incidence of discolored great northern seed harvested from entire fields approached $10 \%$ in some instances (10). Bacterial diseases of dry bean are difficult to manage due to the lack of adequate chemical products. The adoption of minimum tillage or no-tillage farming practices for soil moisture conservation enhances survival of bacterial pathogens and favors new infections in bean crops. Therefore, genetic resistance is generally considered the most effective means of disease management.

The only wilt-resistant cultivar available today is Emerson. However, it is grown as a specialized variety targeted for specific markets in Europe. Therefore, it is not possible for producers to use this cultivar where the disease has been recently found because the market for it is very limited. Bacterial wilt is an emerging problem that requires resistant cultivars adapted for this region. Thus, all entries from the Phaseolus National Plant Germplasm System (NPGS) bean collection were screened for C. flaccumfaciens pv. flaccumfaciens to identify sources of resistance. These efforts to produce a new wilt-resistant, locally adapted cultivar have also 
included screening the University of Nebraska's great northern and pinto dry bean breeding lines, with several current cultivars grown in western Nebraska for comparison.

\section{Materials and Methods}

Germplasm. In total, 467 entries consisting of 427 accessions from the NPGS core collection, 8 cultivars currently grown in western Nebraska (seven great northern and one pinto), and 31 University of Nebraska experimental lines (14 great northern and 17 pinto) were screened for resistance with an orange C. flaccumfaciens pv. flaccumfaciens strain previously recovered from an infected great northern bean plant in Nebraska. The commercially developed great northern cultivars included 'Orion', 'Gemini', 'Beryl-R', 'Marquis', 'Coyne' (18), and 'GN-99136' while 'La Paz' represented the pinto bean market class. Of the NPGS dry bean core collection, 224 accessions originated from Mexico, 101 from Central America, 97 from South America, 4 from Turkey, and 1 of unknown origin. Two commercial cultivars, Orion and Emerson, were additionally used as susceptible and resistant checks, respectively, for all evaluations.

Inoculation. A virulent Nebraska orange variant of $C$. flaccumfaciens pv. flaccumfaciens (Table 1, number 7) isolated originally from a great northern bean plant was used for resistance evaluations. Plants were inoculated at the V2 stage of development (19). One of the two plants in each pot was inoculated by inserting a sterile dissecting needle dipped into a 48 -h bacteria culture between the first and second node $(8,9)$. The second plant was used as a negative control and was punctured in the same manner after dipping a needle in distilled water. The bacterial concentration that accumulated on needles was estimated to be $5.7 \times 10^{8} \mathrm{CFU}$. This estimation was made using two methods of quantifying the CFU. The first method involved producing a suspension of the bacteria from the needle tip in sterile distilled water and visually quantifying it using prepared McFarland Equivalence Turbidity Standards (Remel Scientific; 13). After comparing the sample with the McFarland Standards, an aliquot was removed and quantified using serial dilution plating. In the second method, a 1-ml aliquot of the sample was diluted by factors of 10 , and then a sample of each was plated on nutrient broth yeast agar $(4 \mathrm{~g}$ of nutrient agar, $1 \mathrm{~g}$ of yeast extract, $1 \mathrm{~g}$ of $\mathrm{K}_{2} \mathrm{HPO}_{4}, 0.25 \mathrm{~g}$ of $\mathrm{KH}_{2} \mathrm{PO}_{4}, 1.25 \mathrm{~g}$ of glucose, $8 \mathrm{~g}$ of agar, and $500 \mathrm{ml}$ of deionized water). The sample was autoclaved, $500 \mu \mathrm{l}$ of $1 \mathrm{M} \mathrm{MgSO}_{4} \cdot 7 \mathrm{H}_{2} \mathrm{O}$ was added, and the medium was poured into petri dishes and allowed to cool (20). The procedure was performed in triplicate for each dilution. The plates were incubated at $25^{\circ} \mathrm{C}$ for 2 days and the colonies were counted. The estimated CFU were then determined by multiplying the number of counted colonies by the dilution factor.

Plants were evaluated every 7 days after inoculation using a rating scale of 1.0 to 9.0 based on the percentage of leaf area showing yellow necrotic lesions and wilting, where $1.0=$ no visible to $1.0 \%$ of the primary leaves exhibiting yellow necrotic lesions and wilting, $3.0=$ approximately $10 \%$ of the primary leaves exhibiting yellow necrotic lesions and wilting, $5.0=$ approximately $25 \%$ of the primary leaves exhibiting yellow necrotic lesions and wilting, $7.0=$ approximately $50 \%$ of the primary leaves exhibiting yellow necrotic lesions and wilting, and $9.0=$ more than $75 \%$ of the primary leaves exhibiting yellow necrotic lesions or yellow necrotic lesions and wilting observed in first trifoliate leaves. Ratings of 1.0 to 3.0 (none to less than $10 \%$ incidence) were considered resistant and 4.0 to 5.0 (14.5 to $25.0 \%$ incidence) were intermediate, while any score above 5.1 (more than $25.0 \%$ incidence) was considered susceptible. Starting 7 days after the inoculation, each pot exhibiting a susceptible reaction was removed. Resistant plants (Emerson and PI 325691) were scored up to 49 days after the inoculation. Koch's postulates were conducted on plants from each experiment by reisolating the pathogen. In total, 10 plants randomly selected from each block were sampled to confirm pathogen identity.

Further testing. One accession (PI 325691) (1) was identified as resistant. Thus, it was further evaluated with the two reference checks, Orion and Emerson, by screening with six additional $C$. flaccumfaciens pv. flaccumfaciens strains (Table 1). The genotypes were arranged in a split plot design with four replicates and inoculations were performed three times. The main plots consisted of the different bacterial strains and the subplots were the three genotypes. All inoculation and evaluation procedures were repeated, with the exception of planting 3 seeds/genotype rather than 2, to obtain a higher number of observations for evaluating the responses to the six additional $C$. flaccumfaciens pv. flaccumfaciens strains. Isolations were made from random plants after each inoculation. Pathogen identities were confirmed by observing colony color, gram stain reaction, and colony morphology, thereby completing Koch's postulates. No other pathogens were isolated.

Experimental design. The experiment was repeated four times at four different planting dates at the Panhandle Research and Extension Center at Scottsbluff, NE greenhouse facilities. The genotypes were arranged in an augmented block design. Each block consisted of 23 genotypes and two checks. There were 20 blocks for each planting date. Each experimental unit included a $23-\mathrm{cm}-$ diameter pot planted with 2 seeds/genotype. Fertilization consisted of an application of 20-20-20 (N-P-K) at a rate of approximately $6.2 \mathrm{~g} \mathrm{pot}^{-1} 1$ week after planting. Thrips (Thrips tabaci (Linderman)) were chemically controlled with imidacloprid at a rate of 2.0 g pot ${ }^{-1}$. Daily temperatures of 28 and $22^{\circ} \mathrm{C}$ were maintained in the greenhouse and a 14-h photoperiod was supplemented with $400-\mathrm{W}$ high pressure sodium lights.

Statistical analysis. Statistical analyses were performed using the percentages of leaf area showing yellow necrotic lesions and wilting associated with the above rating scale. Therefore, for a numerical score of 3 (indicating that approximately $10 \%$ of the primary leaves exhibited yellow necrotic lesions and wilting), $10 \%$ was used for the data analysis. Data were analyzed using the PROC MIXED procedure (14). Homogeneity of the variances was evaluated using Barlett's $\chi^{2}$ test (17). Replicates (repeated evaluations) were treated as random effects and genotypes and bacterial strains were treated as fixed effects. In the pooled analyses, planting dates and replicates were random effects and genotypes and strains were fixed effects. Means were separated using an $F$-protected least significant difference test. All tests were considered significant at $P \leq 0.05$ (Table 2).

\section{Results}

Mean bacterial wilt severity values ranged from 1 to 9 (no visible to more than $75 \%$ of the primary leaves exhibiting yellow necrotic lesions and wilting or yellow necrotic symptoms on the first trifoliate leaves and wilting; Table 2). Of the 427 accessions from the NPGS, only 1 (PI 325691) showed resistance (0.23\%), 19 showed intermediate resistance $(4.45 \%)$, and the remainder were susceptible (95.32\%). The resistant and susceptible checks, Emer-

Table 1. Description of Curtobacterium flaccumfaciens pv. flaccumfaciens strains used in the study

\begin{tabular}{llcc}
\hline Strain number & \multicolumn{1}{c}{ Source } & Isolation date & Colony color \\
\hline 1 & Corn leaf & 31 August 2006 & Orange \\
2 & Navy bean seed & 1 February 2007 & Yellow \\
3 & Wheat leaf & 21 July 2006 & Orange \\
4 & Great northern bean seed & 6 February 2008 & Pink \\
5 & Small red bean leaf & 6 September 2006 & Purple \\
6 & Soybean leaf & 31 July 2005 & Yellow \\
7 & Great northern bean seed & 8 September 2004 & Orange \\
\hline
\end{tabular}


son and Orion, resulted in bacterial wilt ratings averaging 1.0 ( $0.5 \%$ incidence) and 7.0 (50.7\% incidence), respectively. The Nebraska breeding lines rated as susceptible, with bacterial wilt ratings of 6.0 to 9.0 (37.5 to $90.0 \%$ incidence), compared with great northern Coyne that produced an intermediate rating of 5.0 (25.0\% incidence) (Table 2). Pathogen identity was confirmed from inoculated plants by consistently reisolating gram-positive, coryneform-shaped bacteria with orange-colored colonies, while no bacteria were isolated from control plants.

The wild bean accession PI 325691 collected from Tzitzio, Michoacán, Mexico, produced the lowest bacterial wilt severity ratings followed by the resistant commercial cultivar Emerson (Table 2). Ratings produced by PI 325691 and Emerson were significantly lower than the other genotypes (Table 2).

Intermediate group (22 entries) reactions were 4.0 to 5.0 (17.5 to $25.0 \%$ incidence), and consisted of 10 landraces from Colombia, Mexico, Guatemala, and Costa Rica; three wild species from Mexico; seven cultivars from Ecuador, Mexico, and the United States, one experimental line; and one accession of unknown origin. Of the great northern cultivars currently grown in Nebraska, Coyne had the lowest bacterial wilt ratings, followed by GN 99136 and Beryl-R. The remaining commercial great northern cultivars, including Gemini, Marquis, Beryl-R, and Orion, and La Paz pinto bean, produced bacterial wilt ratings of 5.0, 7.0, 5.0, 7.0, and 8.0, respectively $(25.0,50.0,25.0,50.0$, and $70.0 \%$ incidence, respectively; Table 2).

Planting dates did not affect bacterial wilt ratings (Table 3). There were no differences among strains (Table 3). However, a significant interaction was observed between planting dates and genotypes, although the ranking was the same in all three planting dates. Bacterial wilt ratings were lower overall at the third planting date, likely because of cooler temperatures outside of the greenhouse at that time of year (around January and February). PI 325691 had lower bacterial wilt ratings than Emerson using strains 2, 3, 4, 5, and 6 (Table 4). Emerson produced the lowest ratings after challenge by $C$. flaccumfaciens pv. flaccumfaciens strains 1 and 7 (Table 4). Orion exhibited the greatest degree of susceptibility and resulted in the highest severity ratings to all $C$. flaccumfaciens pv. flaccumfaciens strains (Table 4).

\section{Discussion}

PI 325691 and Emerson produced resistant reactions to bacterial wilt. PI 165078, PI 201329, PI 207253, PI 313512, PI 318695, and PI 325687 had intermediate reactions from 4.0 to 5.0 (17.5 to $25 \%$ incidence; Table 2) but Schwarz et al. (16) reported average scores between 1.06 and 1.17. The other 32 entries reported by Schwarz et al. (16) as resistant produced susceptible reactions in our conditions of 6.0 to 8.0 (37.5 to $70.0 \%$ incidence; data not shown). The discrepancy is likely due to subjective differences in the severity scale used at the two different locations.

Emerson was released in 1971 as a resistant cultivar by Coyne and Schuster using PI 165078 and GN 1140 as parents (2). The parental source of wilt resistance in Emerson, PI 165078, had an intermediate reaction of 5.0 (25.0\% incidence) in our studies (Ta-

Table 3. $F$ test on percent bacterial wilt incidence from the combined analysis of three planting dates, seven Curtobacterium flaccumfaciens pv. flaccumfaciens strains, and three genotypes evaluated at the Panhandle Research and Extension Center at Scottsbluff, NE greenhouse facilities from 2007 to 2009

\begin{tabular}{lrc}
\hline Source & df & $\boldsymbol{F}$ value $^{\mathbf{a}}$ \\
\hline Date (D) & 2 & $3.14 \mathrm{~ns}$ \\
Strains (S) & 6 & $0.39 \mathrm{~ns}$ \\
D $\times$ S & 12 & $0.26 \mathrm{~ns}$ \\
Genotype (G) & 2 & $64.07 * *$ \\
D $\times$ G & 4 & $15.24 * *$ \\
S $\times$ G & 12 & $0.32 \mathrm{~ns}$ \\
D $\times$ S $\times$ G & 24 & $0.45 \mathrm{~ns}$ \\
\hline
\end{tabular}

a Symbols: $\mathrm{ns}=$ nonsignificant, and $* *=$ significant at $P<0.01$.

Table 2. Bacterial wilt (BW) incidence caused by a virulent Nebraska orange Curtobacterium flaccumfaciens pv. flaccumfaciens strain isolated from great northern bean at the Panhandle Research and Extension Center at Scottsbluff, NE greenhouse facilities from 2007 to 2009

\begin{tabular}{|c|c|c|c|c|c|}
\hline Accession & Origin & Type & Seed color & BW incidence (1-9) ${ }^{\mathrm{a}}$ & BW incidence (\%) \\
\hline PI 325691 & Mexico & Wild & Gray mottle & 0.8 & 0.5 \\
\hline EMERSON & United States & Cultivated & Great northern & 1.0 & 0.5 \\
\hline PI 313490 & Mexico & Landrace & Black & 3.7 & 14.5 \\
\hline PI 201329 & Mexico & Landrace & Brown & 4.1 & 17.9 \\
\hline PI 313444 & Mexico & Landrace & Black & 4.2 & 18.4 \\
\hline PI 318695 & Mexico & Wild & Gray mottle & 4.2 & 18.4 \\
\hline PI 313709 & Mexico & $\ldots$ & Brown & 4.2 & 18.4 \\
\hline PI 325687 & Mexico & Wild & Brown & 4.3 & 18.8 \\
\hline PI 325750 & Mexico & Cultivated & Bayo & 4.3 & 18.8 \\
\hline PI 195402 & Guatemala & Landrace & White & 4.4 & 19.3 \\
\hline PI 313397 & Mexico & $\ldots$ & Bayo & 4.4 & 19.3 \\
\hline PI 136725 & $\ldots$ & $\ldots$ & White & 4.5 & 21.3 \\
\hline PI 165078 & Turkey & Cultivated & White & 4.5 & 21.3 \\
\hline PI 310761 & Guatemala & Landrace & Navy & 4.6 & 21.7 \\
\hline PI 325685 & Mexico & Wild & Black & 4.6 & 21.7 \\
\hline COYNE & United States & Cultivated & Great northern & 4.6 & 21.7 \\
\hline PI 313373 & Mexico & Landrace & Brown mottle & 4.7 & 22.2 \\
\hline PI 313512 & Mexico & Landrace & Bayo & 4.7 & 22.2 \\
\hline GN 99136 & United States & Experimental line & Great northern & 4.7 & 22.2 \\
\hline PI 207253 & Colombia & Landrace & Black mottle & 4.9 & 23.1 \\
\hline PI 209498 & Costa Rica & Landrace & Black mottle & 4.9 & 23.1 \\
\hline PI 313671 & Ecuador & Cultivated & Yellow mottle & 4.9 & 23.1 \\
\hline BERYL-R & United States & Cultivated & Great northern & 4.9 & 23.1 \\
\hline Gemini & United States & Cultivated & Great northern & 5.1 & 25.5 \\
\hline Marquis & United States & Cultivated & Great northern & 6.7 & 45.1 \\
\hline Orion & United States & Cultivated & Great northern & 7.1 & 50.7 \\
\hline $\mathrm{LaPaz}$ & United States & Cultivated & Pinto & 8.2 & 71.8 \\
\hline Average $e^{b}$ & $\ldots$ & $\ldots$ & $\ldots$ & 7.2 & 50.0 \\
\hline $\operatorname{LSD} 0.05^{\mathrm{c}}$ & $\ldots$ & $\ldots$ & $\ldots$ & 2.5 & 7.5 \\
\hline
\end{tabular}

${ }^{\text {a }}$ BW incidence from 1 to 3 was considered resistant (none to $10 \%$ incidence), from 4 to 5 intermediate (14.5 to $25.0 \%$ incidence), and from above 5.1 (more than $25.0 \%$ incidence) susceptible.

${ }^{\mathrm{b}}$ Average from the whole experiment.

${ }^{c}$ Least significant difference. 
Table 4. Bacterial wilt incidence ratings caused by seven different Curtobacterium flaccumfaciens pv. flaccumfaciens strains evaluated at the Panhandle Research and Extension Center at Scottsbluff, NE greenhouse facilities from 2007 to 2009

\begin{tabular}{llllllll}
\hline & \multicolumn{7}{c}{ Rating $(\boldsymbol{\%})$ for strains $^{\mathbf{a}}$} \\
\cline { 2 - 8 } Accession & $\mathbf{1}$ & $\mathbf{2}$ & $\mathbf{3}$ & $\mathbf{4}$ & $\mathbf{5}$ & $\mathbf{6}$ & $\mathbf{7}$ \\
\hline PI 325691 & $2.0(3.7)$ & $1(0.0)$ & $1(0.3)$ & $1(0.9)$ & $1(0.4)$ & $1(0.2)$ & $1(1.7)$ \\
Emerson & $1(0.0)$ & $1(0.9)$ & $2(3.2)$ & $1(1.5)$ & $1(1.2)$ & $2(6.5)$ & $1(0.9)$ \\
Orion & $7(54.2)$ & $5(41.5)$ & $5(32.6)$ & $5(42.2)$ & $5(37.4)$ & $6(47.3)$ & $5(36.1)$ \\
\hline
\end{tabular}

${ }^{a}$ Strain $1=$ orange colony, strain $2=$ yellow colony, strain $3=$ orange colony, strain $4=$ pink colony, strain $5=$ purple colony, strain $6=$ yellow colony, and strain 7 = orange colony. Bacterial wilt incidence from 1 to 3 was considered resistant (none to $10 \%$ incidence), from 4 to 5 intermediate (14.5 to $25.0 \%$ incidence), and from above 5.1 (more than $25.0 \%$ incidence) susceptible.

ble 2). The higher ratings from this introduction compared with the resulting progeny cultivar, Emerson, may suggest a transgressive segregation.

Although Emerson was developed with enhanced bacterial wilt resistance, acreage is limited in Nebraska, in part because of its prostrate growth habit (more prone to white mold [Sclerotinia sclerotiorium (Lib.) de Bary] and common bacterial blight [CBB], and bean common rust [Uromyces appendiculatus (Pers.) Link] susceptibility). It is grown on a small scale in Nebraska for export, primarily to Spain and France. The commercial cultivars and the Nebraska advanced great northern and pinto bean lines tested in this study had intermediate to high ratings, indicating the need for sources of bacterial wilt resistance. Although Coyne was bred specifically for adaptation to Nebraska growing conditions and for enhanced resistance to CBB, a major disease of common bean caused by the seedborne bacterium Xanthomonas axonopodis pv. phaseoli (Smith) Dye (syn. X. axonopodis pv. phaseoli (Smith) Vauterin et al.), in 2011, a number of Nebraska dry bean growers noted that Coyne additionally had lower quantities of orange- or yellow-discolored seed compared with other cultivars after delivery to the elevator, suggesting lower levels of wilt infection (personal observation, data not included).

Results from four separate evaluations showed that $95.6 \%$ of the U.S. dry bean core collection was susceptible to bacterial wilt, and only $4.2 \%$ showed variable responses. The major cultivars currently grown in western Nebraska (Marquis, Orion, Gemini, and La Paz) were highly susceptible but inoculations on Coyne and Beryl-R resulted in intermediate reactions to bacterial wilt. This suggests that resistance is present in these cultivars (Coyne and Beryl R), or they may have partial resistance to bacterial wilt.

Only one entry, PI 325691 (1), was identified from the germplasm collection as a true source of bacterial wilt resistance. This resistance remained stable after multiple inoculations with seven $C$. flaccumfaciens pv. flaccumfaciens strains. PI 325691 is a wild common bean (P. vulgaris) originally collected at a location 8 miles south of Tzitzio, Michoacán, Mexico (latitude $19^{\circ} 28^{\prime} 0^{\prime \prime} \mathrm{N}$, longitude $100^{\circ} 50^{\prime} \mathrm{W}$, and elevation of $1,330 \mathrm{~m}$ ). PI 325691 is also registered in the collection at the International Center for Tropical Agriculture (CIAT) as G 12883 (1). Seed size of PI 325691 is small (5.3 g 100 $100^{-1}$ seeds) and will require several backcrosses to transfer this disease resistance into a commercially acceptable dry bean. PI 325691 has a shiny cream and black mottled color and a climbing growth habit but, unfortunately, it is susceptible to Bean common mosaic virus and Empoasca leafhoppers (Empoasca fabae (Harris)) (1).

Thus, it is important to continue evaluating germplasm for potential sources of resistance to bacterial wilt. We are currently evaluating CIAT's dry bean core collection, comprising 1,700 accessions, utilizing the same methodology as described. Mapping of the resistant genes will be performed and resistance genes will be combined into new cultivars through hybridization. Introgression of bacterial wilt resistance genes should enhance the economic impact of the high-yielding bacterial wilt disease-resistant cultivars. Release of bean cultivars with disease resistance will lower production costs and potentially reduce pesticide use for Central High Plains dry bean producers.

\section{Acknowledgments}

Financial support of the Layman Grant, the Nebraska Dry Bean Commission, and hatch project (NEB43-103) is acknowledged. We thank K. Nielsen, A. Koehler, and J. Thomas for technical support; and the NPGS GRIN for providing seed for our evaluations.

\section{Literature Cited}

1. CIAT. 2012. Genetic Resources Program. http:///www.ciat.cgiar.org/urg

2. Coyne, D. P., and Schuster. M. L. 1971. 'Emerson' The new large-seeded great northern dry bean variety. Nebr. Agric. Exp. Stn. Bull. SB 516:1-11.

3. EPPO/CABI. 1997. Curtobacterium flaccumfaciens pv. flaccumfaciens. Pages 991-994 in: Quarantine Pests for Europe, 2nd ed. I. M. Smith, D. G. McNamara, P. R. Scott, and H. Holderness, eds. CAB International, Wallingford, UK.

4. Harding, M. W., Marques, L. R., Howard, R. J., and Olson, M. E. 2006. Biofilms are involved in vascular clogging and seed infection by Curtobacterium flaccumfaciens pv. flaccumfaciens in bean vascular wilt. (Abstr.) Phytopathology 96:S46.

5. Harveson, R. M., Giesler, L. J., Jackson, T. A., Wegulo, S. N., and Timmerman, A. D.. 2011. Dry bean disease profiles I. Univ. Nebr. Coop. Ext. ECO5-1876.

6. Harveson, R. M., and Schwartz, H. F. 2007. Bacterial diseases of dry edible beans in the central high plains. Plant Health Progress. Online publication. doi:10.194/PHP-2007-0125-01-DG

7. Harveson, R. M., Schwartz, H. F., Vidaver, A. K., Lambrecht, P. A., and Otto, K. L. 2006. New outbreaks of bacterial wilt of dry bean in western Nebraska observed from field infections. Plant Dis. 90:81.

8. Harveson, R. M., and Vidaver, A. K. 2007. First report of the natural occurrence of soybean bacterial wilt isolates pathogenic to dry beans in $\mathrm{Ne}$ braska. Plant Health Progress. Online publication. doi:10.1094/PHP-20070822-01-BR

9. Harveson, R. M., and Vidaver, A. K. 2008. A new color variant of the dry bean bacterial wilt pathogen (Curtobacterium flaccumfaciens pv. flaccumfaciens) found in western Nebraska. Plant Health Progress. Plant Health Progress. Online publication. doi:10.1094/PHP-2008-0815-01-BR

10. Harveson, R. M., Vidaver, A. K., and H. F. Schwartz. 2005. Bacterial wilt of dry beans in western Nebraska. NebGuide, University of Nebraska, G05$1562 \mathrm{~A}$.

11. Hedges, F. 1926. Bacterial wilt of beans (Bacterium flaccumfaciens Hedges) including comparison with Bacterium phaseoli. Phytopathology 16:1-21.

12. Hsieh, T. F., Huang, H. C., and Erickson, R. S. 2006. Bacterial wilt of common bean: Effect of seed borne inoculum on disease incidence and seedling vigour. Seed Sci. Technol. 34:57-67.

13. McFarland, J. 1907. Nephelometer: an instrument for estimating the number of bacteria in suspensions used for calculating the opsonic index and for vaccines. J. Am. Med. Assoc. 14:1176-1178.

14. SAS Institute. 2004. User's Guide: Statistics. SAS Institute, Cary, NC.

15. Schuster, M. L., and Smith, C. C. 1983. Surveillance and seed transmission of three strains of Corynebacterium flaccumfaciens in beans (Phaseolus vulgaris L.). Fitopatol. Bras. 8:87-91.

16. Schwarz, H. F., Brick, M. A., Otto, K., and Ogg, J. B. 2010. Germplasm evaluation for resistance to bacterial wilt in common bean, 2008-2009. Plant Dis. Manage. Rep. 4:V125.

17. Steel, R. G. D., and Torrie, J. H. 1980. Principles and Procedures of Statistics. A Biometrical Approach. McGraw-Hill, Inc., New York.

18. Urrea, C. A., Steadman, J., Pastor-Corrales, M., Lindgren, D., and Venegas, J. P. 2009. Registration of great northern common bean cultivar 'Coyne' with enhanced disease resistance to common bacterial blight and bean rust. J. Plant Regul. 3:1-4.

19. van Schoonhoven, A., and Pastor-Corrales, M. A. 1987. CIAT. Standard Evaluation of Bean Germplasm. Centro Internacional de Agricultura Tropical (CIAT), Cali, Colombia.

20. Vidaver, A. K. 1967. Synthetic and complex media for the detection of fluorescence of phytopathogenic pseudomonads: Effect of the carbon source. Appl. Microbiol. 15:1523-1524. 